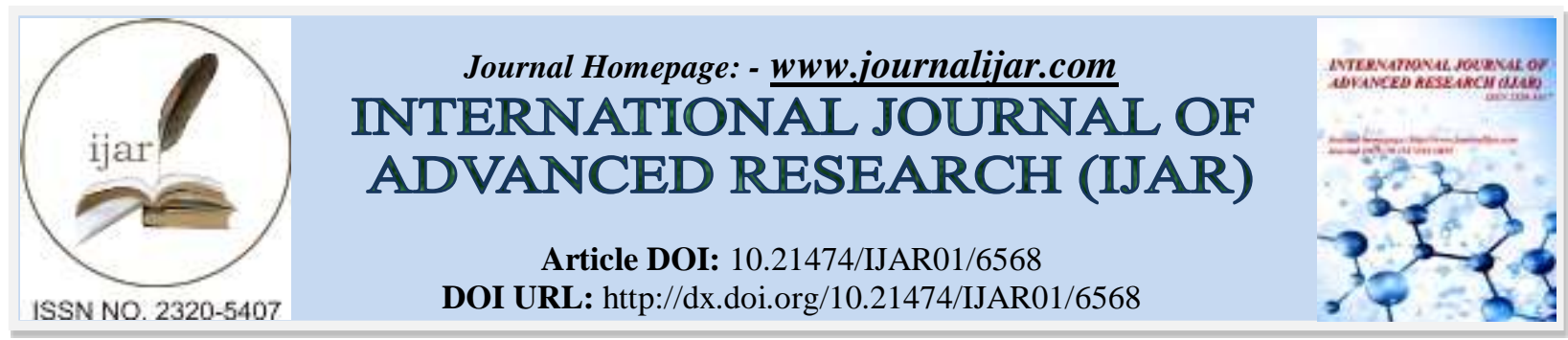

RESEARCH ARTICLE

\title{
THE EFFECTIVENESS OF PHYSICS TEXTBOOK USED BASE ON IMAGE PROCESS TO INCREASE STUDENT COGNITIVE LEARNING OUTCOMES.
}

\author{
Durrotun Ni’mah, Sutarto, Sudarti, Indrawati, Supeno, Agus Abdul Gani and Jekti Prihatin. \\ Department of Post Graduate Science Education, Jember, University of Jember, Indonesia.
}

\section{Manuscript Info}

Manuscript History

Received: 17 December 2017

Final Accepted: 19 January 2018

Published: February 2018

Key words:-

Effectiveness, textbook, image process,

learning outcomes.

\begin{abstract}
This research is aimed to describe the effectiveness of physics textbook used base on image process to increase student cognitive learning outcomes. The subject of this research is ten $(\mathrm{X})$ grade of Zainul Bahar Islamic Senior High School 2017-2018 period. The research methodology is such experimental which designs one group pretest and posttest. Collecting data technique is using test. Analysis data technique to determine effectiveness of using $\mathrm{N}$-gain formula. Base on data analysis result obtained an increase learning outcomes for each class (XA, XB and XC) respectively are 0,77 (high category); 0,72 (high category); and 0,69 (medium category). Thus it can be concluded that the textbook used base on image process can increase student learning outcome.
\end{abstract}

Copy Right, IJAR, 2018,. All rights reserved.

\section{Introduction:-}

In $21^{\text {st }}$ century learning process prosecute teacher to be able in preparing the generation that competitively afford with society in the future (Siburian, 2013). Besides, education in $21^{\text {st }}$ century change the pradigma of teaching teachers wich early use a learning approach teacher centered lerning (TCL) nowdays it has developed and move to become student centered learning (SCL). The pradigma movement of teaching is hopefully able to motivate student actively in constructing knowledge, attitude and behaviour (Trinova, 2013). Chik (2016) started that student centered learning invite them to be more active and self confident the teachers is only as facilitator. Students who active in learning activity is very significant and must be present in every lerning activity, espesially in science field.

Science is knowledge which learning about natural acquired in controlling way through several processes to produce the product (Muslichah, 2006). Supriyatman and Sukarno (2014) clarify that natural science in a knowledge which emphasize in the process and product because it is including the study of natural phenomena systematically through several activities to find some particulars. Student who learns science need to be directed toward understanding the concept because the essential of learning science are process and product as well as its application. However, not only natural science, but physics also include disciplines emphasized toward process and product.

Physics as one of science branch considered can give positive contribution in spurring science and technology, therefore it is important to improve education quality (Rahardjo and Hidayah, 2013). The success of physics learning can be viewed from many factors; one of them is the improvement of student cognitive learning outcomes. It is a result of an interaction in the learning and teaching action related to the achievement of teaching objectives (Dimyati and Mudjiono, 2006). The best learning outcomes can achieve by doing the maximum learning activities

Corresponding Author:- Durrotun Ni'mah.

Address:- Department of Post Graduate Science Education, Jember, University of Jember, Indonesia. 
from student in the learning process. Assessment of learning outcomes is very important because it can determine the level of student ability during the learning process.

Hamalik (2004) proposes that learning objectives can be achieved better if it is supported by several factors such learning media. It is also started by Mukminan and Saliman (2008), that media is one of factor which can determine the success of learning because it helps student and teachers to convey the subject material. There are several media subject that can be used in school such as worksheet, module, book package and so on. The media images according to Sudjana (2007) is a media that combines facts and ideas clearly and strongly through combination words and images. The image will be more meaningful when accompanied by stages or sequences till it can visualize natural phenomena related to physics. The meaning of the process is the stages of certain event (Kamus Ilmiah Populer: 2006). If the definition of image and process media are combined, so media image process is media that can visualize natural phenomena through stages or sequences images logically, regularly and can help readers to understand it quickly.

The research that is conducted by Prasetyo (2012) indicates that student who are learning with a diagram or image have higher achievement than students who are only using text. Due to image media, student can imagine and connect to natural phenomena from subject material. Hence, the student can understand the material easily the excess use of image media such as learning will be more interesting, fun, facilitate student to understand the material, learning will not be bored, the users are more easily due to the printed from that has various color therefore, it can create student reading interest. Angkowo and Kosasih (2007) states that image media or graphic media have several advantages, one of them can attract student interest in learning. According to Arsyad (2011) visual learning media plays an important role in the learning process. Visual media can facilitate understanding and strengthen student memory. It can inspire student learning interest and connect to content of learning materials with the real world. Visual media can be media images, comics, caricatures and many others.

One of the learning media raised in this research is textbook that can be used in learning process. The textbook is material used in the field of particular student arranged by expert systematically till it can facilitate learning process. Textbook is a unit that contains information, discussion and evaluation which are arranged systematically and facilitate student to understand the material thus supporting the achievement of learning objectives (Mintowati, 2003). Considering the nature of science learning in the form of process-product, then the learning media that will be used in this research are physics textbook base on image process.

\section{Methodology:-}

This research use quasi experimental research with design one group pretest and posttest design (Figure 1). The subject of this study (small class) is 10 students for two meeting. The first meeting discusses about momentum and the second meeting discusses about impulse. Then proceed with the class scale test of research subject for 20 students class XA, 20 students class XB and 22 students class XC of Zainul Bahar Islamic Senior High School which consist of two meeting of each classes. The first meeting discusses about momentum conservations law and the second meeting discuss about collision. The research is conducted in December 2017 at Zainul Bahar Islamic Senior High School for a month.

\section{$\mathrm{O}_{1} \mathrm{X} \mathrm{O}_{2}$}

Figure 1:- Research design one group pretest and posttest design

Information:

$\mathrm{O}_{1} \quad=$ Pretest

$\mathrm{O}_{2} \quad=$ Posttest

$\mathrm{X} \quad=$ learning treatment uses physics textbook base on image process.

This research data consist of quantitative data obtained from essay test such as pretest and posttest. Then the value data of pretest and posttest calculates using in the following formula:

$$
\langle\mathrm{g}\rangle=\frac{\text { actual gain }}{\text { maximum gain }}=\frac{\text { posttest score }- \text { pretest score }}{\text { maximum score }- \text { pretest score }}
$$

For the achievement level criteria of N-Gain as following: 
Table 1:- The achievement level criteria of N-Gain

\begin{tabular}{|l|l|l|}
\hline No. & The average N-Gain Intervals & Criteria \\
\hline 1. & $0,70 \leq\langle g\rangle \leq 1,00$ & High \\
\hline 2. & $0,30 \leq\langle g\rangle<0,70$ & Medium \\
\hline 3. & $0,00 \leq\langle g\rangle<0,30$ & Low \\
\hline
\end{tabular}

Physics textbook base on image process is related effective, if minimal N-Gain qualify "medium" criteria with value between 0,30 to 0,70 .

\section{Result and Discussion:-}

The effectiveness of physics textbook base on image process can be category effective in learning if understanding test result of momentum concept and impulse obtain $\mathrm{N}$-Gain value with average minimal criteria. The result of pretest, posttest and $\mathrm{N}$-Gain average on small class test can be checked in table 2 .

Table 2:- Pretest, posttest and N-Gain value on small class test

\begin{tabular}{|l|l|l|l|l|l|}
\hline Meeting & Material & Pretest & Posttest & N-Gain & Criteria \\
\hline 1 & Momentum & 17,6 & 74,3 & 0,69 & Medium \\
\hline 2 & Impuls & 17,4 & 77,4 & 0,73 & High \\
\hline Average & 17,5 & 75,85 & 0,71 & & \\
\hline
\end{tabular}

Small class test for the first meeting obtains pretest average for about 17,6 and posttest amounts 74,3. N-Gain for the first meeting (small class) obtain 0,69 score in medium criteria. The second meeting obtains pretest value average for about 17,4 and posttest value average 77,4. N-Gain for this second meeting obtains 0,73 score in high criteria. Textbook base on image process qualify effective criteria for learning on small class. With the result that can be continued for class scale test. There are pretest, posttest and N-Gain value for class scale test in the following table.

Table 3:- pretest, posttest and $N$-Gain value at class scale test

\begin{tabular}{|l|l|l|l|l|l|l|l|l|l|}
\hline \multirow{2}{*}{ Material } & \multicolumn{3}{|l|}{ Class XA } & \multicolumn{3}{l|}{ Class XB } & \multicolumn{3}{l|}{ Class XC } \\
\cline { 2 - 10 } & Pretest & Posttest & N-Gain & Pretest & Posttest & N-Gain & Pretest & Posttest & N-Gain \\
\hline $\begin{array}{l}\text { Conservation of } \\
\text { momentum law }\end{array}$ & 18,45 & 80,15 & 0,75 & 17,7 & 75,4 & 0,70 & 16,9 & 74,6 & 0,69 \\
\hline Collision & 21,85 & 83,7 & 0,79 & 16,45 & 78,85 & 0,75 & 16,4 & 75,23 & 0,70 \\
\hline Average & 20,15 & 81,9 & 0,77 & 17,07 & 77,12 & 0,72 & 16,65 & 74,91 & 0,69 \\
\hline N-Gain Criteria & High & \multicolumn{7}{|l|}{ High } \\
\hline
\end{tabular}

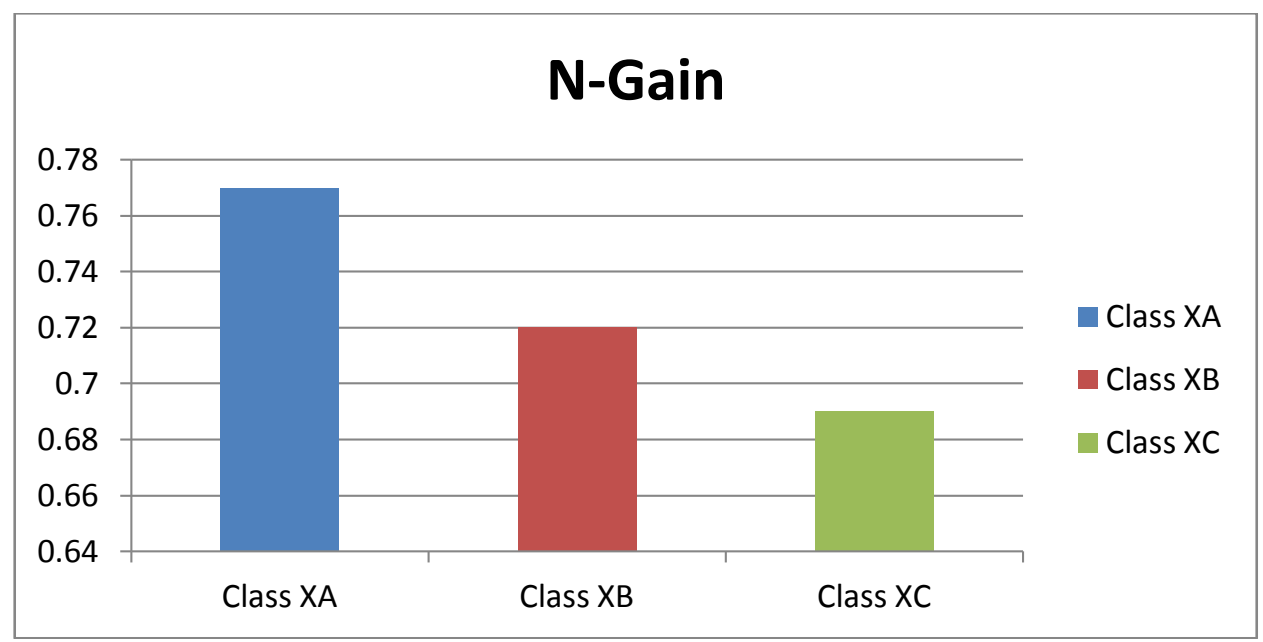

Figure 2:- N-Gain average for class XA, class XB and class XC

Class scale test is conducted twice for meeting in each class; these are class XA, class XB and class XC. The material for the first meeting is momentum conservation law and the second meeting is about collision. The result of 
pretest average score for class XA, class XB and class XC are 20,15; 17,07 and 16,65 while the posttest average score for class XA, class XB and class XC are 81,9; 77,2 and 74,91. The biggest $\mathrm{N}$-Gain obtained by class XA with 0,77 in high category, then class $\mathrm{XB}$ with 0,72 in high category and class XC with 0,69 in medium category. XGain result for each class indicate that physics textbook base on image process which has developed effectively to use in learning at Islamic senior high school.

\section{Conclusion:-}

The conclusion of the result study is clarified that physics textbook base on image process qualify effective criteria used in learning physics. Base on data analysis result obtained an increase learning outcomes for each class (XA, $\mathrm{XB}$ and $\mathrm{XC}$ ) respectively are 0,77 (high category); 0,72 (high category); and 0,69 (medium category). Average increase of $\mathrm{N}$-Gain for each class are 0,73 (high category).

\section{Reference:-}

1. Angkowo, R., \& Kosasih, A. (2007). Optimalisasi Media Pembelajaran. Jakarta: PT. Grasindo.

2. Arsyad, Azhar. 2011. Media Pembelajaran . Jakarta: PT Raja Grafindo Persada

3. Chik, Norlaila Abdullah. 2016. Action Research: Student's Communication Skill through Peer Learning Method (Regional Development-GMJT3124) Group B. Journal of Education and Social Policy

4. Dimyati Dan Mujiono. 2006. Belajar dan Pembelajaran. Jakarta: PT.Rineka Cipta

5. Gitamedia Press. 2006. Kamus Ilmiah Populer. Gitamedia Press: Surabaya

6. Hamalik, O. 2004. Kurikulum dan Pembelajaran. Bandung : Bumi Aksara

7. Mintowati. 2003. Pedoman Penulisan Buku Ajar. Depdikbud: Jakarta

8. Mukminan, \& Saliman. 2008. Teknologi Informasi dan Media Pembelajaran Ilmu Pengetahuan Sosial. Yogyakarta: Universitas Negeri Yogyakarta.

9. Muslichah, Asyari. 2006. Penerapan Pendekatan Sains-Teknologi-Masyarakat Jakarta: Departemen Pendidikan Nasional

10. Sanjawa, W,. 2007. Stretegi Pembelajaran: Berorientasi Standar Proses Pendidikan. Jakarta : Media Predana

11. Siburian, dkk. 2013. Pengaruh Penerapan Model Pembelajaran Berdasarkan Masalah terhadap Penguasaan Konsep Fisika Fluida Statis dan Kemampuan Berpikir Kritis Siswa. Jurnal Pendidikan Sains Pascasarjana Universitas Negeri Surabaya, Vol. 1, No. 2, Januari 2013.

12. Sugiyono. 2016. Metode Penelitian Kuantitatif, Kualitatif, dan $R \&$ \& . Bandung: Alfabeta

13. Supriyatman dan Sukarno. 2014. Improving Science Process Skils (SPS) Science Concept Mastery (SCM) Prospective Student Teachers Throught Inquiry Learning Instruction Model By Using Interactive Computer Simulation. International Journal of Science and Research (IJSR).

14. Trinova, Zulfia. 2013. Pembelajaran Berbasis Student-Centered Learning pada Materi Pendidikan Agama Islam. Jurnal Al-Ta'lim Fakultas Tarbiyah dan Keguruan IAIN Imam Bonjol Padang, Jilid 1, No. 4, Februari 2013. 